\title{
Eimeria curvata n. sp. (Apicomplexa: Eimeriidae) in Columbina talpacoti and Scardafella squammata (Aves: Columbidae) from Brazil
}

\author{
Edson A Adriano/ ${ }^{+}$, Patricia J Thyssen, Nelson S Cordeiro \\ Departamento de Parasitologia, Instituto de Biologia, Universidade Estadual de Campinas, Caixa Postal 6.109, \\ 13083-970 Campinas, SP, Brasil
}

Eimeria curvata is a new coccidian described in the doves Columbina talpacoti and Scardafella squammata from western of the State of São Paulo, Brazil. The oocysts are ovoid to ellipsoid, 18.3 (1719) $\mu \mathrm{m} \times 15.5$ (15-17) $\mu \mathrm{m}$, with a shape index of 1.2 (1.1-1.3). The wall is colorless, smooth and doublelayered. A polar granule is present, but there is no micropyle or oocyst residuum. The sporocysts are elongate, 12.3 (11.5-13) $\mu m x$ x.8 (5.5-6) $\mu \mathrm{m}$ with a curved anterior portion and a smooth, thin, singlelayered wall. The Stieda body is protuberant and nipple-like; there is no substieda body. The sporozoites lie head-to-tail in the sporocyst and contain a large refractile body at the extremities. The sporocyst residuum contains small granules uniformly distributed in the middle of the sporocyst. The prevalence of E. curvata $n$. sp. was $17.4 \%$ and $12.8 \%$ in C. talpacoti and S. squammata, respectively.

Key words: Eimeria curvata n. sp. - Columbina talpacoti - Scardafella squammata - coccidia - Apicomplexa Brazil

At least 65 species of the family Columbidae occur in the neotropical region (Stotz et al. 1996). Columbina talpacoti Temminck, 1810, a small dove found in dry, open areas such as fields and farms as well as around human dwellings (Hilty \& Brown 1986), occurs mainly in the tropics and, occasionally, in the subtropics (Schauensee \& Phelps Jr 1978). Scardafella squammata Lesson, 1831, another small columbid, is also common in arid scrub areas and around dwellings. This species occurs only in the neotropics (Schauensee \& Phelps Jr 1978).

There is no record of coccidian parasites in these columbid species. In this paper, we report in both $C$. talpacoti and S. squammata the occurrence of a previously undescribed Eimeria species. The parasite is described as a new species of Eimeria.

\section{MATERIALS AND METHODS}

Forty-six adult specimens of C. talpacoti and 39 adult specimens of $S$. squammata were captured using gauze-traps (Ibama 1994) in the municipality of Junqueirópolis, in western of the State of

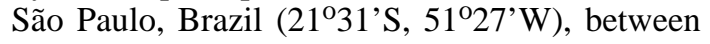

\footnotetext{
This study was supported by Capes.

${ }^{+}$Corresponding author. Fax: +55-19-289.3124. E-mail: andrian@obelix.unicamp.br

Received 25 May 1999

Accepted 22 November 1999
}

January and December 1998. The birds were housed individually in appropriate cages for $2 \mathrm{~h}$, tagged and then released. Faecal samples from all birds were stored in $2.5 \%$ potassium dichromate solution $\left(\mathrm{K}_{2} \mathrm{Cr}_{2} \mathrm{O}_{7}\right)$, maintained at room temperature $\left(23-28^{\circ} \mathrm{C}\right)$ and examined microscopically after flotation using Sheather's sugar solution.

Photomicrographs were obtained using a Zeiss Standard microscope and Kodak TMAX 100 film. Thirty-six oocysts and 32 sporocysts were measured and compared with those of Eimeria species already reported for the family Columbidae. All measurements and averages are given in $\mu \mathrm{m}$, followed by the range within parentheses and then by the shape-index (ratio of length/width).

\section{RESULTS}

Eight out of 46 C. talpacoti and five out of 39 S. squammata were found to contain coccidial oocysts. Morphological differences were observed between these oocysts and all other known Eimeria spp. from Columbiformes. This finding lead us to regard this oocyst as belonging to a new species of Eimeria. The parasite is described below.

\section{Eimeria curvata $\mathrm{n}$. sp.}

(Figs 1-5)

Description: ovoid to ellipsoidal oocysts (Figs 12) $(n=36), 18.3(17-19) \times 15.5$ (15-17); shape index 1.2 (1.1-1.3). The bilayered wall is 1.3 thick, and is composed of a colourless outer layer 0.9 thick, and a brown inner layer 0.4 thick. Micropyle and oocyst residuum are absent. A polar gran- 
ule is present (Fig. 1). Sporocysts elongate (Figs $3-5)(n=32), 12.3(11.5-13) \times 5.8(5.5-6)$, shape index 2.1 (2-2.2), with a curved anterior portion and a smooth, thin, single-layered wall (Figs 3-5). Sporozoites lie head-to-tail in the sporocyst, each with a large refractile at the extremities. There is a protuberant, nipple-like Stieda body (Figs 4-5) but no apparent substieda body. The sporocyst residuum is composed of small granules uniformly concentrated in the middle of the sporocyst.

Sporulation time: not determined.

Site of infection: unknown. Oocysts observed in the faeces.
Type material: phototypes of oocysts are deposited in the Department of Parasitology, Institute of Biology, State University of Campinas, State of São Paulo, Brazil (n. 10/99).

Type host: Columbina talpacoti Temminck, 1810 (Aves: Columbidae).

Additional host: Scardafella squammata Lesson, 1831 (Aves: Columbidae).

Locality: municipality of Junqueirópolis, western

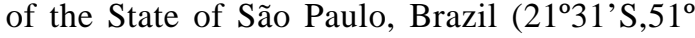
27'W).

Prevalence: 8/46 (17.4\%) C. talpacoti and 5/39 (12.8\%) S. squammata were infected.

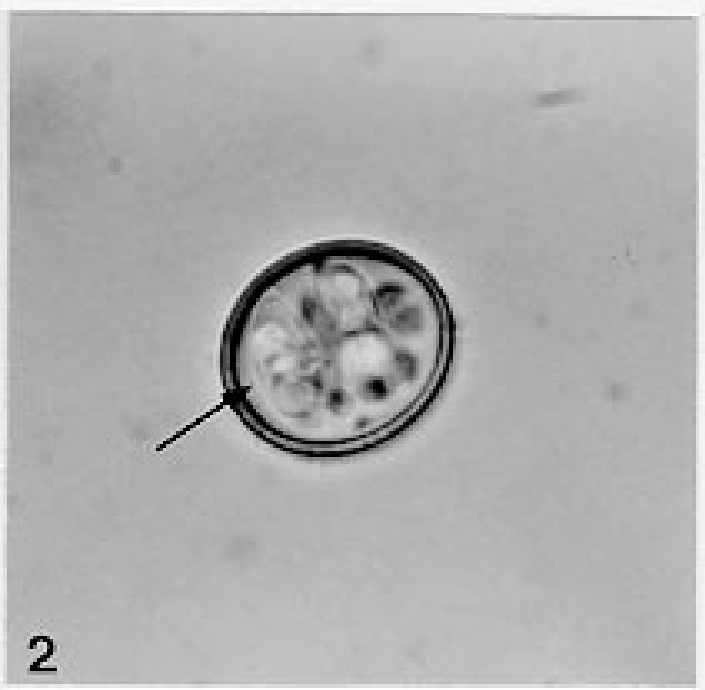

1
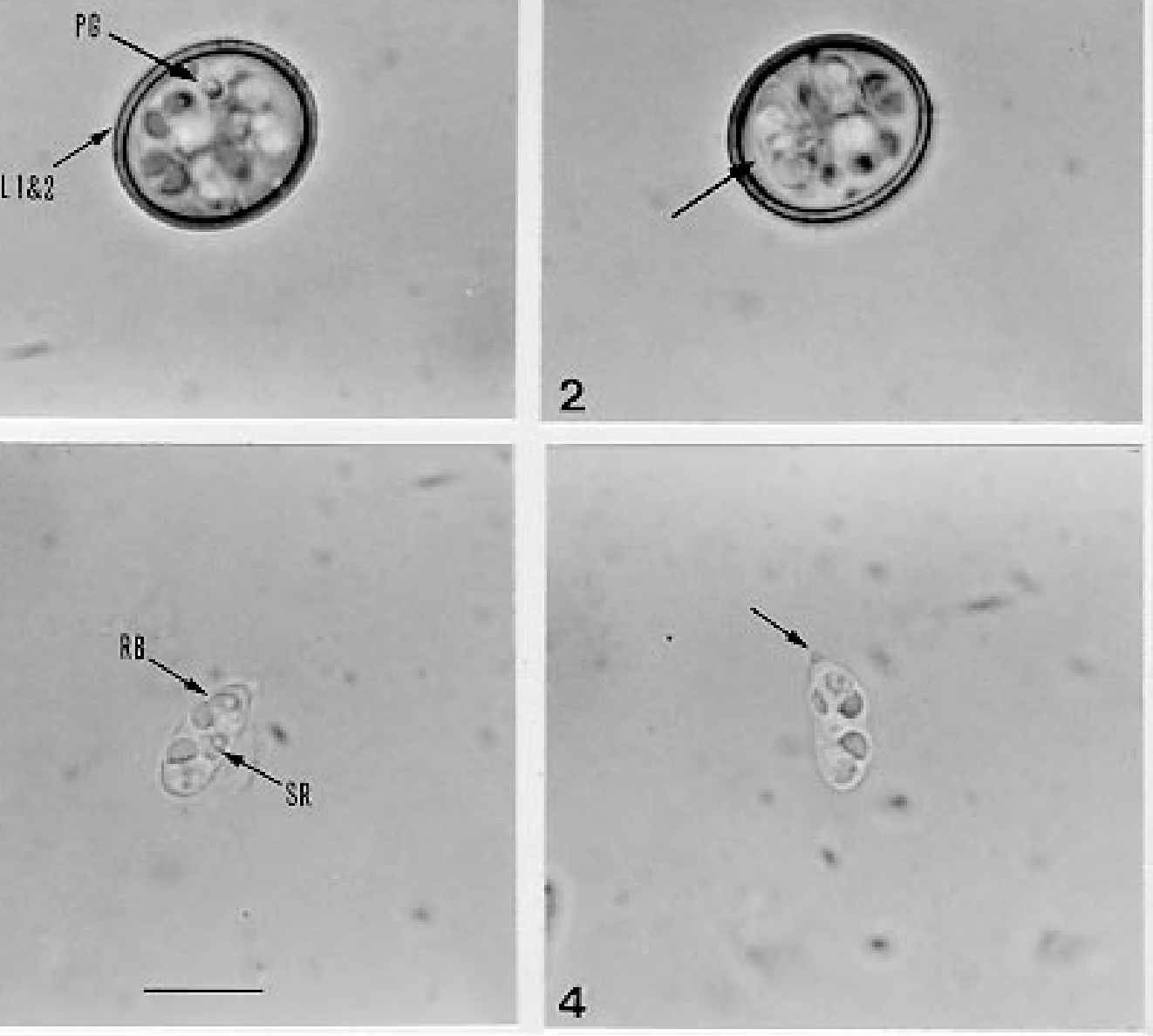

Photomicrographs of sporulated oocysts of Eimeria curvata n. sp. Fig. 1: cross-section of oocyst wall showing a colorless outer layer $\left(\mathrm{L}_{1}\right)$ and a brown inner layer $\left(\mathrm{L}_{2}\right)$. Note the polar granule (PG). Fig. 2: mature oocyst. Note the sporocyst. Photomicrographs of free sporocysts. Fig. 3: note the sporocyst residuum (SR) and refractile body (RB) in the extremities of the sporozoites. Fig. 4: protuberant Stieda body. Bar $=10 \mu \mathrm{m}$. 


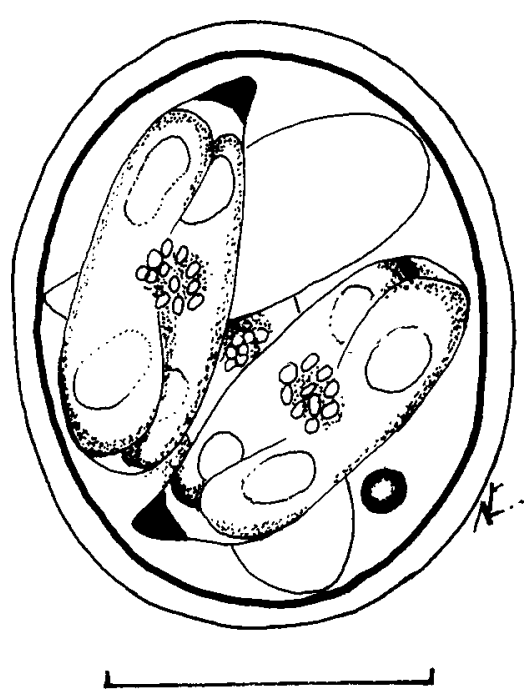

Fig. 5: line-drawing of a mature oocyst of Eimeria curvata n. sp. $\operatorname{Bar}=10 \mu \mathrm{m}$.

Pathogenicity: infected doves appeared healthy. The histopathology of the infection remains to be studied.

Etymology: the species name is based on the curved appearence of the sporocysts.

\section{DISCUSSION}

So far, only ten species of coccidian parasites have been described from Columbiformes (McQuistion 1991). These are E. labbeana Pinto, 1928, E. columbarum Nieschulz, 1935, E. columbae Mitra and Das-Gupta, 1937, E. tropicalis Malhotra and Ray, 1961 and E. kapotei Chatterjee and Ray, 1969, all parasites of Columba L., 1758 species; E. waiganiensis Varghese, 1978 of Chaloephaps indica L., 1758 and Otidiphaps nobilis Gould, 1870; E. gourai Varghese, 1980 of Goura victoria Fraser, 1844; E. duculai Varghese, 1980 of Ducula spilorrhoa Gray, GR, 1858; E. palumbis McQuistion, 1990 of Zenaida galapagoensis Gould, 1839 and Isospora gallicolumbae Varghese, 1978 of Gallicolumba beccarii Salvadori, 1876.

This is the first report of an Eimeria species in Columbina Spix, 1825 and Scardafella Bonaparte, 1855. Comparison of E. curvata n. sp. with the nine previously described species mentioned above shows that the oocysts this new especies of Eimeria most resemble those of $E$. columbae. However, the oocysts of E. curvata n. sp. can be easily distinguished from those of E. columbae as they have only one polar granule, no oocyst residuum and a curved anterior portion of the sporocyst.

Lillehoj and Trout (1993) pointed out that Eimeria are generally very host-specific, with no species naturally infecting more than one host species. However, Long (1990) asserted that closely related species or subspecies may serve as adequate hosts for a given species of Eimeria. According to Lainson (1992), host specificity of Eimeria species is relatively strictly maintained, at least within host genus. Varghese (1978) reported E. waiganiensis in both $C$. indica and $O$. nobilis. According to the same author, E. labbeana also was reported parasitizing two species of host of two different genus C. livia and Streptopelia orientalis Latham, 1790. In the same way, E. curvata n. sp. was found in C. talpacoti and S. squammata suggesting that some Eimeria species of Columbiformes are specific at the family level.

\section{REFERENCES}

Hilty SL, Brown WL 1986. A Guide to the Birds of Colombia, Princeton University Press, New Jersey, 836 pp.

Ibama 1994. Manual de Anilhamento de Aves Silvestres, 2 ed., Instituto Brasileiro do Meio Ambiente e dos Recursos Naturais Renováveis, Brasília, 148 pp.

Lainson R 1992. A protozoologist in Amazonia: neglected parasites, with particular reference to members of the Coccidia (Protozoa: Apicomplexa). Ciên Cult 44: 81-93.

Lillehoj HS, Trout JM 1993. Coccidia: a review of recent advances on immunity and vaccine development. Avian Pathol 22: 3-31.

Long PL 1990. Coccidiosis of Man and Domestic Animals, CRC Press, Florida, USA, p. 47-48.

McQuistion TE 1991. Eimeria palumbi, a new coccidian parasite (Apicomplexa: Eimeriidae) from the Galapagos dove (Zenaida galapagoensis). Trans Am Microsc Soc 110: 178-181.

Schauensee RM, Phelps Jr WH 1978. A Guide to the Birds of Venezuela, Princeton University Press, New Jersey, 424 pp.

Stotz DF, Fitzpatrick JW, Parker TA, Moskovits DV 1996. Neotropical Birds. Ecology and Conservation, The University of Chicago Press, Chicago and London, $478 \mathrm{pp}$.

Varghese T 1978. Eimeria waiganiensis sp. n. from the green-winged ground dove (Chalcophaps indica Linnaeus) and the magnificent ground pigeon (Otidiphaps nobilis Gould) in Papua New Guinea. $J$ Parasitol 64: 312-314. 